\section{Loss Reserve Error in the Brazilian Insurance Market: empirical evidence of the response to economic and tax regulations}

\author{
Rodrigo da Silva Santos Curvello ${ }^{1}$ \\ Adriano Rodrigues ${ }^{1}$ \\ Marcelo Alvaro da Silva Macedo ${ }^{1}$ \\ ${ }^{1}$ Federal University of Rio de Janeiro, \\ Accounting Department, Rio de Janeiro, Brazil
}

Received on

12/07/2016

Approved on

04/02/2018

Responsible editor:

Prof. Dr. Ivam Ricardo Peleias

Evaluation process:

Double Blind Review

\begin{abstract}
Purpose - This study aims to investigate whether insurance companies operating in the property and casualty lines manage their loss reserves in order to avoid further regulatory scrutiny and/or to reduce income tax values.
\end{abstract}

Design/methodology/approach - This research is empirical-analytical and employs econometric modeling of specific discretionary accruals applied to a sample of 50 insurers operating in the Brazilian market analyzed during the period from 2008 to 2013.

Findings - We found evidence of managerial discretion in loss reserves with the purpose of managing income tax for the period and also to give the impression of better solvency to both the insurance authority and the market, thus avoiding further regulatory intervention and favoring asymmetry. Moreover, the best performing companies tend to overestimate their loss reserves by reducing their profits to levels that do not alert the regulatory authority. This can be related to the practice of income smoothing.

Originality/value - It is the first study in the Brazilian insurance market that utilizes the loss reserve errors in a specific accruals model to jointly study their impacts and three motivations for managers' opportunistic behavior in relation to claims provisions.

Keywords - Loss reserve error. Insurance. Earnings management. Tax regulation. Economic regulation.

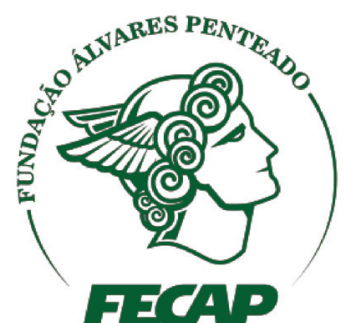

Review of Business

Management

DOI: $10.7819 /$ rbgn.v0i0.2942 


\section{Introduction}

Earnings quality may be impacted by aspects related to the management of reported accounting numbers because their informative content is directly related to the subjective component of profit, i.e. accruals, which increase or decrease the information asymmetry between the firm and the market (Lopes \& Martins, 2005).

Investigating managerial discretion in relation to accruals becomes even more relevant if viewed from the perspective of the potential impact on risk-based economic regulation (supervision). This supervisory model addresses the solvency of insurers by comparing regulatory capital, based on the risks to which insurers are exposed, with their available capital, defined as the difference between the accounting balances of eligible assets and liabilities (Melo \& Neves, 2012).

Among the liabilities reported by insurers are the technical reserves related to claims (losses), whether these are reported by insureds (Outstanding Claims Provision - OCP) or not (Incurred But Not Reported Loss - IBNR). These reserves are initially measured by estimate and subsequently revised as new information becomes available on the severity and rate of reported losses until they are actually settled. In the international literature, the amount added or subtracted from the initial measurement is called the loss reserve error (Grace \& Leverty, 2012).

As noted by Rodrigues (2008), the amounts recorded in such reserves directly affect the net income of insurers and, therefore, the equity used for measuring their solvency, thus also affecting the reviews.

In addition, since 2008, this kind of measurement has been used as a parameter for several supervisory measures in the Brazilian insurance market (CNSP Resolution No. 178, of 2007). Thus, managers who work in this market may be encouraged to manage their earnings in order to avoid drawing the regulatory authority's attention to a potential difficulty in making future payments in connection with incurred liabilities.
Also, the corporate income tax (IRPJ) and social contribution on net profits (CSLL) regulations stipulate that the technical reserves recorded by insurers shall be deducted in the determination of taxable income (Decree No. 3000, 1999). Therefore, as reported in the study by Gaver and Paterson (1999), managers may use the discretion inherent to the measurement of claim reserves with the intention of reducing income tax payments.

In view of the above, this study intends to answer the following research question: is there any evidence that Brazilian insurers manage earnings through claim reserves as a response to economic and tax regulations?

Therefore, the main objective of this research is to investigate whether the insurers that operate in property and casualty insurance adopt the practice of managing accounting information by means of claim reserve accounts (OCP and IBNR) in response to the risk-based economic regulations and income tax regulations imposed by the federal government.

It is important to mention that this research differs from that of Rodrigues (2008), mainly due to the use of the loss reserve error as a dependent variable in the proposed model and the model proposition that considers joint tax and regulatory incentives and income smoothing, as considered in international studies. Moreover, in this study, unearned premium reserves (UPR) were not used because they differentially affect insurers' results due to the accrual basis and the recognition formula established in SUSEP's rules, with less discretion except as to current risks with policies not yet issued.

In this sense, the research is potentially capable of filling gaps in the understanding of the subject at the national level, due to the lack of Brazilian research that use specific accruals models in which the dependent variable comprises estimation errors to study the impacts and aspects that affect managers' opportunistic behavior regarding the measurement of insurance claim reserves. 


\section{Theoretical Framework}

\section{I Regulation in the Brazilian insurance market}

Preliminarily, it is necessary to clarify what is being referred to as economic regulation. According to Posner's studies, "properly defined, the term refers to taxes and subsidies of all sorts as well as to explicit legislative and administrative controls over rates, entry, and other facets of economic activity" (Posner, 1974, p. 335).

Among the theories of regulation is the Public Interest Theory, for which regulation allows private initiative to respond by supply, but restricts the choices of regulated companies, deciding on pricing, the entry and exit of companies in the market, and the establishment of products and services, among others (Stigler, 1971).

This theory resembles the private powers of the National Council for Private Insurance (Conselho Nacional de Seguros Privados CNSP), including: (a) establishing general norms of accounting and statistics to be observed by insurance companies; and (b) limiting the capital of insurance and reinsurance companies. It should be emphasized that while the CNSP regulates the market, the Superintendency of Private Insurance (Superintendência de Seguros Privados - SUSEP) supervises and issues instructions via circular newsletters (Decree-Law No. 73, 1966).

A mechanism to reduce informational asymmetry and delimit the capital of supervised parties allows the State to monitor the liquidity, solvency, and investments of those parties, especially the assets legally related to technical provisions, in addition to preserving the interests of consumers, promoting the stability of that market, and ensuring the liquidity and solvency of the companies that make up the market, thus ensuring balanced expansion and functioning.

In response to the financial crises that occurred in the 2000s, the supervisory mechanisms of the global insurance market have undergone significant changes with the prospect of adopting the Solvency II project. According to the European Insurance and Occupational Pensions Authority (EIOPA, 2013), "The Solvency II project aims to review the prudential regime for insurance and reinsurance companies in the European Union.”. Directive 2009/138/EC of the European Parliament and of the Council of the European Union, approved in November 2009 and in force since 1/1/2016, establishes the project guidelines.

In general, three pillars support the project: a quantitative pillar with calculation methodologies for capital requirements based on underwriting, credit, operational, and market risks and technical provisions (Pillar 1); a qualitative one with guidelines for supervisory activities and controls based on these risks (Pillar 2); and a final one associated with the disclosure of information, including financial reporting (Pillar 3).

At this point, it is appropriate to establish the relationship between the accounting information of the insurance market and the economic regulation currently practiced.

Since 2008, according to CNSP Resolution No. 178 (2007), the Minimum Capital Requirement (MCR) has been compared to the Capital Resources Available (CRA) - an adjusted equity measure - and, if the balance is positive, there is sufficiency in the solvency parameter; otherwise, there is insufficiency. Depending on the number of months of insufficiency in the parameter, the regulator may initiate actions in order for the company's capital to return to the desired level (CNSP Resolution No. 282, 2013).

Therefore, the ratio is determined by calculating the CRA, which is the equity minus assets that are not accepted by the regulator to meet obligations assumed in the event of oscillations and adverse situations (CNSP Resolution No. $222,2010)$. As equity is the residual interest in the company's assets, after deducting all its liabilities, it suffers all sorts of interference from the discretion exercised over the accounting measurements performed (Accounting Pronouncements Committee [Comitê de Pronunciamentos Contábeis - CPC], 2011). 
It is important to highlight the regulatory and solvency frameworks of the studied market: risk-based capital requirement rules have been implemented since $1 / 1 / 2008$, but a good part of risk capital has only been required since January of 2011, and international accounting standards were applied as of $1 / 1 / 2010$ to consolidated balance sheets and as of 1/1/2008 for individual balance sheets, with a more intense adoption in 2009 (Susep Circular No. 355, 2007; Susep Circular No. 356, 2007; Susep Circular No. 408, 2010; CNSP Resolution No. 178, 2007).

Among the accounting standards adopted are Technical Pronouncement CPC 11 - Insurance Contracts, equivalent to the international standard IFRS 4 - Phase I, whose main objective was to specify the accounting recognition for insurance contracts by any entity that issued them. It is recalled that the structural changes were postponed to phase II of the comprehensive insurance project, expected for the first half of 2017. Thus, the phase I regulations only introduced limited improvements in accounting for these contracts and encouraged more efficient explanatory note disclosure, capable of more clearly identifying and explaining the values resulting from these contracts in the financial reporting of these companies based on minimum information on the uncertainties in cash flows, risk, and equity position. In Brazil, CPC 11 was initially applied in the preparation of the consolidated statements for 2010 and the individual statements of 2011. Among the additional disclosures required is the claims development table, used in this research as a data source for the calculation as detailed in Appendix A. For Zsoldos (2014), insurers are exposed to the insurance underwriting risk, where the threat of an inadequate technical provision constitutes the most relevant portion. The liability adequacy test (LAT) would be one tool to mitigate this danger of insolvency.
Among other contributions from phase I, Costa (2005) highlights the introduction of the LAT of insurance contracts. In this test, insurers should compare, at each balance sheet date, existing liabilities, minus deferred acquisition costs and related intangible assets (Net Carrying Amount), with estimates of future cash flows calculated from current assumptions.

The LAT is therefore a test that consists of an actuarial calculation of current estimates of future cash flows associated with insurance contracts (Martire, 2012). The intention of the IASB was to create a mechanism to reduce the possibility that significant losses would remain unrecognized during the first phase of the project (Bagnati, 2012). In Brazil, after the publication of CPC 11 via Susep Circular No. 408/10, the LAT was initially regulated by Susep Circular No. $410 / 10$ and shall be performed on the dates of June 30 and December 31, the end of the periods covered by the interim and annual financial statements of the insurance market, respectively. In June 2012, Circular No. 446 suspended the effects of the aforementioned regulations, thus exempting insurance companies from carrying out the test in the preparation of their interim individual financial statements for June 2012. In December 2012, a new guideline, Circular No. $457 / 12$, once again required Brazilian insurance companies to perform the test on the same dates mentioned but using a timelier update of the calculation and explaining the technical criterion used in the actuarial study (Susep Circular No. 410, 2010; Susep Circular No. 446, 2012; Susep Circular No. 457, 2012).

Gonçalves (2015) summarizes the legislation applicable to the LAT for each reporting period, according to Table 1 . 
Table 1

\section{LAT legislation applicable to companies supervised by SUSEP}

\begin{tabular}{ll}
\hline Period / Year & Applicable Legislation \\
\hline 1st Half / 2010 & SUSEP Circular No. 410/2010 \\
2nd Half / 2010 & SUSEP Circular No. 410/2010 \\
1st Half / 2011 & SUSEP Circular No. 410/2010 \\
2nd Half / 2011 & SUSEP Circular No. 410/2010 \\
1st Half / 2012 & Suspension - LAT Obligation - \\
2nd Half / 2012 & SUSEP Circular No. 457/2012 \\
1st Half / 2013 & SUSEP Circular No. 457/2012 \\
2nd Half / 2013 & SUSEP Circular No. 457/2012 \\
1st Half / 2014 & SUSEP Circular No. 457/2012 \\
\hline
\end{tabular}

Thus, during the period analyzed in this study, the two regulations of the LAT were valid. Therefore, the reestimates calculated in 2011 for the incurred claims in 2008 may have been impacted by the test according to Susep Circular No. 410/10, while the reestimates assessed in 2012 and 2013, related to incurred claims in 2009 and 2010, respectively, may have been influenced by the test as required by Susep Circular No. 457/12.

However, it should be noted that both Susep regulations required the adjustment of the amounts established for the claims obligations to be accounted directly in the respective provision considered insufficient (OCP, IBNR, or incurred but not enough reported losses - IBNER). Currently, with the relocation of the IBNER to the interior of the OCP (Susep Circular No. 517, 2015), the following alternatives are possible: if the inadequacy is in the OCP, the insurer should, whenever possible, individually amend the claims registered below the calculated amount. If this detailed correction is not possible, the company must make the change through the IBNER, an aggregate adjustment currently contained in the OCP. If the inadequacy is in the IBNR, which in itself is an aggregate estimate, there is no need to talk about an individual adjustment. The insurer should redo the estimate and directly adjust the provision.
In turn, the tax regulation on profit in the Brazilian insurance market naturally follows the general dictates of the Constitution (1988) and regulations of Decree No. 3000 (1999) (RIR / 99). Therefore, the income of these companies is determined by the actual income regime (Lucro Real system), and so both the corporate income tax and the social contribution on net profits.

The IRPJ rates practiced are found in the general rule of progressivity determined in article 228 of the RIR / 99, that is, a base rate of $15 \%$, with an additional $10 \%$ on the monthly installments that exceed $\mathrm{R} \$ 20,000$ actual ( $\$$ 240,000 per year). However, the CSLL has a higher tax rate of $15 \%$ on the profits of insurance companies (the general rate is 9\%) (Decree No. 3000, 1999; Law No. 7689, 1988).

In addition, the most significant specific rule refers to the deductibility of technical provisions constituted by the requirement of special legislation applicable to insurance companies, raffle-linked savings companies, and publicly-held private pension entities. Thus, the provisions for claims whose subjectivity is inherent may be deducted from profit for the purposes of calculating taxable income, reducing the amount of tax due (Decree No. 3000, 1999).

Thus, considering the natural development of the claims provisions and the overview of the tax legislation described, it can be concluded that the constitution of these provisions can be used to reduce or delay the payment of taxes.

\subsection{Discretionary accounting information}

According to Healy and Wahlen (1999), earnings management is based on the judgments made by managers in the disclosure of financial information and in the structuring of transactions to alter financial reports, in order to deceive some interested parties with regard to company performance or to influence contractual results that depend on the accounting numbers disclosed.

Regarding the forms of management, Paulo (2007) cites: (i) the use of discretionary accruals; (ii) changes in operating activities; (iii) 
manipulating the classification of the elements of financial statements; and (iv) manipulation by improper measurement of equity elements, especially those of the Balance Sheet.

Earnings management through specific discretionary accruals can occur via the choice of timing of the recognition element and / or the choice of accounting measurement criterion, which is the center of attention in the current literature (Cardoso, 2005).

In the specific case of insurance companies, uncertainties about the exact amount of the obligation due to the insured in relation to a claim occurring (advised or not) allow the manager to manage the initial and subsequent measurement of the loss provision, recorded in the liabilities of the company with direct consideration in the income for the period.

On the possible incentives for managers to manage earnings found in the literature, Healy and Wahlen (1999) highlight: (a) capital market expectations, since accounting numbers are used by analysts and investors in valuations; (b) contracts drawn up on the basis of accounting numbers, including the bonus plan hypothesis, where managers raise the results of the period because they receive variable remuneration and thus achieve alignment with the objectives of the owners, and the debt covenant hypothesis, where more indebted companies have more incentive to use methods that increase earnings by transferring profits from future results to the current period; and (c) government regulation in specific markets, such as capital requirements by the regulator and the establishment of tariffs.

Still on this point, the political costs hypothesis, developed in the positive theory of accounting, starts from the premise that high profits tend to attract attention from, among others, regulatory agencies, consumer protection agencies, and environmentalists. This hypothesis predicts that large corporations (or companies with high social and environmental visibility or a monopoly) will use techniques to reduce profits more often than small firms (Watts \& Zimmerman, 1990).

Thus, the hypothesis suggests a relationship without a formal contract between governmental intervention and the accounting numbers of companies. The causal relation derives from the political visibility of the firm subject to the various forms of governmental intervention (regulation), including: minimum investment requirements for companies that cause negative socio-environmental externalities; increased taxation; and increased minimum regulatory capital, as in the case of banks (and insurers) (Holthausen \& Leftwich, 1983).

\subsection{Research on loss reserve errors and their motivations}

The following are the main studies on discretionary accounting information in insurers. Weiss (1985), using a sample of 16 major automobile insurers between 1955-1975, tested and confirmed the hypotheses (significant negative relation) of income smoothing and the influence of external economic factors (interest and unanticipated inflation) on the loss reserve errors of auto insurance lines.

Later, Grace (1990) investigated whether this estimation error was motivated by the reduction in federal tax payments and / or smoothing of income disclosed in the years 1966 to 1979 by 61 insurers. Until 1972, the provisioning practice only helped to reduce tax accounts (positive and significant relation), but from 1972 to 1979 , the cause of the estimation errors began to include income smoothing (negative and significant relation) and changes in inflation indices.

Petroni (1992) started from Grace's (1990) study to investigate a sample of 324 insurers (1322 observations) for the period 1979-1983 and confirmed the hypothesis that financially weak insurance managers skewed claims provisions (positive and significant coefficient), even after controlling for other factors such as the tax rate and external economic factors (increasing 
coefficients over time, becoming significant in 1983). These results broadened those of Grace (1990) and are consistent with the view that managers seek to reduce costs associated with financial weakness by applying discretion in accounting estimates, even when this implies sacrificing tax minimization policies.

Gaver and Paterson (1999) found that insurers in the period 1990-1995 (4,173 firmyear observations) managed their levels of claims provisions. The findings confirmed a reduction in management incentives to achieve the solvency target due to the adoption of risk-based capital requirements in 1994. They also reported that the tax incentive is positive and significantly associated with the provision errors over the entire period and that there is a positive and significant relationship between the annual percentage evolution of the earned premiums (non-discretionary component) and the estimation errors.

In a sample of 11,460 observations for the period 1988-1997, Beaver, McNichols, and Nelson (2003), using frequency and regression distribution, found evidence that insurers with small positive results underestimated claims provisions compared to insurers with small negative results. In addition, the claims provisions were managed for the entire distribution of profits, with more accruals that improve the result being reported in smaller profits and more accruals that worsen the result being disclosed in higher earnings.

Gaver and Paterson (2004) deepened the evidence of Petroni (1992) and Beaver et al. (2003) by reporting that insurers (6,233 observations) managed claims provisions in the period 19881993 to avoid breaching the indicators used by US regulators. The results indicated that solvency targets are also an important influence on discretionary accounting choice and suggest that the manipulation of provisions may postpone regulatory intervention, sometimes for a long period.

Based mainly on Petroni (1992), Beaver et al. (2003), and Gaver and Paterson (2004), and
Brazilian standards, Rodrigues (2008) investigated earnings management through technical provisions as a response to the economic and tax regulations of the Brazilian insurance market from 2001 to 2006 , with 360 observations. The evidence confirmed the positive and significant relationship between technical provisions and the values of solvency parameters and taxes. In addition, the author found a positive and significant relationship between the provisions and the size factor, and a negative and significant one in relation to the performance factor. However, the author mentions that it was not possible to use the loss reserve error, since it was not available.

Noting the gap in the literature, Eckles and Halek (2010) related the studies of tax incentives and regulatory and income smoothing with those of contractual executive compensation incentives and evidenced a negative relationship between compensation with more bonuses and the provision of loss for a sample of 348 observations from 1992 to 2004 . However, they did not find a statistical relation for the granting of stock options, the granting of shares, or long-term incentive plans. Eckles, Halek, He, Sommer, and Zhang (2011) also reported that managers with higher bonuses and stock awards tended to make provisioning decisions that diminished corporate profits. In addition, managers were more likely to manipulate provisions in the presence of certain board structures.

Finally, in relation to the joint impact of fiscal motivations, solvency, income smoothing, and rate regulation on the measurement of claims provisions, and using two definitions of provision error, Grace and Leverty (2012) found: (a) evidence for the tax incentive increasing the loss provision, but only with the error of Kazenski, Feldhaus, and Schneider (1992); (b) weak evidence that managers smoothed results; (c) a greater tendency to overestimate the provision in companies subject to higher levels of price regulation and with a higher percentage of premiums issued in a highly regulated environment; (d) strong evidence of underestimation by financially weak 
insurers, without it being possible to assert that the objective is to avoid the costs of close regulatory verification, since financial fragility, income smoothing, moral hazard, or difficulty in establishing estimates losses could lead to underprovisioning and thereby reduce the number of breaches of financial indicators.

Table 2

\section{Main findings on the management of claims provisions}

\begin{tabular}{|c|c|c|c|}
\hline Author (year) & Sample (country) & Period & Main findings (coefficient sign) \\
\hline Weiss (1985) & $\begin{array}{l}16 \text { biggest auto insurers } \\
\text { (USA) }\end{array}$ & $\begin{array}{l}1955- \\
1975\end{array}$ & Smoothing $(+)$ and external economic factors \\
\hline Grace (1990) & 61 ins. (USA) & $\begin{array}{c}1966- \\
1979\end{array}$ & Tax incentive $(+)$, smoothing $(-)$, and external factors \\
\hline Petroni (1992) & $\begin{array}{l}324 \text { ins. (USA) } 1,322 \\
\text { firm-year obs. }\end{array}$ & $\begin{array}{l}1979- \\
1983\end{array}$ & $\begin{array}{l}\text { Regulatory incentive }(+) \\
\text { obs .: sacrificing the reduction of taxes }\end{array}$ \\
\hline $\begin{array}{l}\text { Gaver and Paterson } \\
\text { (1999) }\end{array}$ & $\begin{array}{l}\text { ins. (USA) } \\
4,173 \text { firm-year obs. }\end{array}$ & $\begin{array}{l}1990- \\
1995\end{array}$ & $\begin{array}{l}\text { Tax incentive }(+) \\
\text { obs .: reduction of regulatory incentive after CBR }\end{array}$ \\
\hline Beaver et al. (2003) & $\begin{array}{l}\text { ins. (USA) } \\
11.460 \text { firm-year obs. }\end{array}$ & $\begin{array}{l}1988- \\
1997\end{array}$ & $\begin{array}{l}\text { Small profits - underestimation } \\
\text { Big profits - overestimation }\end{array}$ \\
\hline $\begin{array}{l}\text { Gaver and Paterson } \\
(2004)\end{array}$ & $\begin{array}{l}\text { ins. (USA) } \\
6,233 \text { firm-year obs. }\end{array}$ & $\begin{array}{l}1988- \\
1993\end{array}$ & Regulatory incentive $(+)$ \\
\hline Rodrigues (2008) & $\begin{array}{l}60 \text { ins. (BRA) } 360 \\
\text { firm-year obs. }\end{array}$ & $\begin{array}{l}2001- \\
2006\end{array}$ & $\begin{array}{l}\text { Tax incentive }(+) \text {, regulatory incentive }(+) \text {, size }(+) \text {, and performance } \\
(+)\end{array}$ \\
\hline Eckles and Halek (2010) & $\begin{array}{l}63 \text { ins. (USA) } 348 \\
\text { firm-year obs. }\end{array}$ & $\begin{array}{l}1992- \\
2000\end{array}$ & Executive compensation package with more bonuses (-) \\
\hline Eckles et al. (2011) & $\begin{array}{l}54 \text { ins. (USA) } 311 \\
\text { firm-year obs. }\end{array}$ & $\begin{array}{l}1992- \\
2004\end{array}$ & Higher bonuses and stock awards (-) and board structures $(+)$ \\
\hline $\begin{array}{l}\text { Grace and Leverty } \\
(2012)\end{array}$ & $\begin{array}{l}\text { ins. (USA) } 5,459 \text { firm- } \\
\text { year obs. }\end{array}$ & $\begin{array}{l}1990- \\
1997\end{array}$ & $\begin{array}{l}\text { Tax incentive (KFS error) }(+) \text {, weak evidence of smoothing, rate } \\
\text { regulation }(+) \text {, and financial weakness }(+)\end{array}$ \\
\hline
\end{tabular}

Note. The findings are listed based on the literature review presented.

Table 2 summarizes the findings of the literature reviewed. It remains to be seen whether the behavior of managers in the Brazilian market is in line with those of the North American market and whether the use of technical provisions errors, as a measure of bias, maintains the results found by Rodrigues (2008). The fact that the Brazilian market is less developed may alter the behavior of managers in Brazil, either because of technical ignorance or because of greater conservatism in the studied environment. In addition, the regulatory and accounting changes in Brazil make this research even more important.

\subsection{Development of hypotheses}

Based on the literature presented on managers' incentives to influence the measurement of claims provisions, three hypotheses were formulated for the relationship between the estimation errors committed by insurance companies and economic regulatory requirements, taxation, and profit performance.

Grace (1990), Peñalva (1998), Gaver and Paterson (1999), Nelson (2000), and Beaver et al. (2003) found evidence of a strong positive 
association between the estimation errors in US insurers and their taxable profit before reported errors. Rodrigues (2008) also detected this incentive in the Brazilian market but did not operate the dependent variable in the same way, due to the unavailability of data. It should be emphasized that other studies did not find this relationship, such as Petroni (1992). Also, the study by Grace and Leverty (2012) found that the tax incentive depends on the calculation of the estimation error. In addition, the provisions for claims are deductible for the purposes of taxation on profit in Brazil and the nominal rate applied on insurers is higher than that of other sectors. Therefore, the following hypothesis was developed:

$\mathbf{H}_{1}$ : Insurance companies with higher values of income taxes overvalue their initial measurement of claims provisions (positive estimation errors).

In addition, Petroni (1992), Harrington and Danzon (1994), Gaver and Paterson (2004), and Rodrigues (2008) found evidence that insurers' directors use their discretion in the measurement of claims provisions in order to ensure that they are more solvent and thereby avoid the costs of closer scrutiny or even intervention by the regulator. With this, a second hypothesis was formulated:

$\mathbf{H}_{2}$ : Insurance companies with lower levels of solvency understate their initial measurement of claims provisions (negative estimation errors).

In addition, according to research by Weiss (1985), Grace (1985), Rodrigues (2008), Eckles and Halek (2010), and Eckles et al. (2011), insurers with high performance levels are more likely to overvalue (or underestimate less) their technical provisions for claims, in order to smooth their income, thus avoiding both drawing the regulator's attention to abnormal income and the payment of higher amounts of taxes on profit. Therefore, a third hypothesis closely related to the previous ones was formulated:

$\mathbf{H}_{3}$ : Top performing insurance companies overvalue their initial measurement of claims provisions (positive estimation errors) to smooth net income.

\section{Methodology}

\section{I Typology and sampling}

This research is of a descriptive, positivist, and empirical-analytical nature, as it seeks empirical evidence that the supervisory model adopted and the tax regulation encourage insurer manager discretion in the measurement of claims provisions, also establishing relationships between the errors in these provisions and possible incentives found in the literature.

The sampling process was nonprobabilistic. It was based on the list of companies supervised by Susep and initially selected for the investigation only insurance companies that sold property and casualty products in the years 2008 to 2010 and which disclosed, in their notes to the 2013 financial statements, the claims development table in a model that allowed the extraction of claims balances occurring up to the 2008, 2009, and 2010 financial years re-estimated at the end of 2011,2012, and 2013, respectively.

Subsequently, the companies that, at the end of 2008, 2009, and 2010, presented a balance of provisions for claims (OCP and IBNR) only for branches or groups of characteristics are relevant for separate studies. The following branches and groups of branches were selected for this exclusion: mandatory DPEM and DPVAT insurances (groups 04 and 05), individual and group life insurances and private pensions (groups 06 and 09), and individual and private pension microinsurances (branches 1601 and 1603).

The year 2010 was chosen as the last exercise of the study. This is because there must be a gap between the date of constitution and 
the restatement of an event that allows the development of this event. In international studies, a 5-year interval is common with the justification that almost $100 \%$ of claims are paid within that time period. In this study, we chose to use a 3-year interval, excluding companies that had not paid by December 2011, 2012, and 2013 (subsequent three years) more than $90 \%$ of the balances of their end-of-year loss provisions of 2008, 2009, and 2010, respectively. In the end, a sample of 133 firm-year observations (50 insurers listed in Appendix A) was obtained, considering the completeness of the information necessary for the study. Table 3 details the sampling process and presents the number of observations obtained.

Table 3

Sampling process used in the study

\begin{tabular}{|c|c|c|}
\hline & Stages of the Sampling Process & Amount \\
\hline & Companies authorized to operate in the Brazilian insurance market - Dec / 2013 & 176 \\
\hline$(-)$ & Publicly-held private pension entities, local reinsurance companies, and raffle-linked savings companies & $(57)$ \\
\hline$(-)$ & Absence of disclosure of the claims development table in the explanatory notes of Dec / 2013 & $(50)$ \\
\hline$(=)$ & Companies whose estimation errors in each year can be analyzed & 69 \\
\hline (x) & 3 selected exercises & 207 \\
\hline$(-)$ & $\begin{array}{l}\text { Disclosure of the claims development table in the explanatory notes of Dec / 2013, which begins after 2008, } \\
2009 \text {, or } 2010\end{array}$ & $(17)$ \\
\hline$(-)$ & Has not settled until $t+3$ amount equal to or greater than $90 \%$ of the provision constituted in $t$ & $(48)$ \\
\hline$(-)$ & $\begin{array}{l}\text { Absence of claims provisions for the property and casualty insurance lines (except DPVAT, DEPEM, and } \\
\text { microinsurance) in } 2008,2009 \text {, or } 2010\end{array}$ & (9) \\
\hline$(=)$ & Total observations & 133 \\
\hline
\end{tabular}

After the selection, a description was carried out of the content of the notes to the financial statements of 2013 using a quantitative approach, based on a collection tool developed during the survey, similar to the claims development table, but with specific fields for the calculation and extraction of the estimation errors of the claims provisions developed.

In addition, most of the previous studies do not use traditional criteria for the removal of outliers (winsorization, deviations from the mean, and difference of quartiles, among others). However, some studies (e.g. Beaver et al., 2003; Grace \& Leverty, 2012; Petroni, 1992) use, as a criterion for the withdrawal of these observations, the existence of extreme differences, in absolute terms, between the initial estimate and the revised estimate. For this study, a 100\% value was used as the criterion, since the use of the more restricted and common criterion of $50 \%$, besides reducing the number of observations to questionable numbers (105 observations), would not make the dispersion levels of variables similar to international studies, in addition to not substantially altering the test results regarding the assumptions of the regression model used.

\subsection{Variables and study model}

To test the hypotheses, we selected six variables operationalized as such:

ERROR (dependent) - refers to the estimation errors of the insurer's claims provisions (OCP and IBNR). Its value is the difference between the initial estimate of claims incurred for company $i$ in a given year $t$ and the estimated amount of claims incurred for company i in calendar year $t+j$, with $j=3$, scaled by the total profits of company i, according to Grace (1990), Kazenski, Feldhaus, and Schneider (1992) and Grace and Leverty (2012).

Therefore, positive errors indicate that the company is overvaluing the initial measurement of the loss provision and, thus, reducing the earnings for the period in which the claim is recorded. On 
the other hand, negative errors indicate that the insurer is underestimating the technical provision of loss and, therefore, increasing the earnings for the period in which the claim is recorded.

IRCS (independent) - is given by the sum of the adjusted balances of the corporate income $\operatorname{tax}($ IRPJ) and social contribution on net profits (CSLL), scaled by the total of the recognized assets of company $i$ in calendar year $t$.

Considering that IRPJ and CSLL are influenced by the estimation error, whose variations we intend to explain, the adjusted value of IRPJ and CSLL was calculated before the effects of the estimation error. Initially, the nominal rate (40\%) was applied on the estimation error identified. This product was then added to or subtracted from the IRPJ and CSLL expense taken from the insurer's Income Statement in order to find the value of the expense without the effect of the respective estimation error. This obtained the amount of taxes on profit before the judgment on loss provisions, which is a value closer to that used in manager's decision-making.

Most previous studies, such as Grace (1990), Peñalva (1998), Nelson (2000), Gaver and Paterson (1999), Beaver et al. (2003), Rodrigues (2008), Eckles and Halek (2010), and Grace and Leverty (2012), have found evidence that insurers use the provisioning of claims obligations to reduce the levels of tax due. Thus, considering the high Brazilian tax burden on insurers, we expect to find a positive and significant sign for the IRCS coefficient.

SUFCAP\% (independent) - is one of the solvency evaluation parameters used from 2008 in the Brazilian insurance market to monitor the companies supervised by Susep. This parameter is calculated as follows: (a) the difference between (i) capital resources available (CRA), the adjusted equity after excluding assets that are not capable of determining, in a strict and qualitative way, the resources available to enable supervised companies to carry out their activities in the face of fluctuations and adverse situations; and (ii) the minimum capital requirement (MCR), the highest value between the solvency margin (SM) and the sum of the capital base with the additional risk capital in force (CNSP Resolution No.
178, 2007; CNSP Resolution No. 282, 2013). Then, this is divided by the minimum capital requirement.

Likewise, the CRA adjusted for this error (net of tax effects) was used and no adjustment was made in MCR due to the complexity of its calculation regarding the underwriting risk. However, as a robustness test of the model, the solvency parameter calculated for the previous month (November) was used for the one analyzed, without significant differences being found. It is an approximation of the number used by managers when deciding to exercise discretion over the provisions studied.

Like previous papers by Petroni (1992), Gaver and Paterson (1999), Gaver and Paterson (2004), Rodrigues (2008), and Grace and Leverty (2012), it was identified that financial and solvency insurance companies tended to underestimate claims provisions, which may end or delay most of the costs of thorough scrutiny by the regulator, so that there is a positive and significant coefficient for SUFCAP\%.

NETMAR (independent) - net margin calculated from net income of insurer $i$ in calendar year $\mathrm{t}$ adjusted by the estimation error (net of taxation).

The research by Weiss (1985), Grace (1990), and Beaver et al. (2003) found evidence of the practice of income smoothing in insurers using estimates of claims provisions, so we expect to find a positive and significant relation for NETMAR, demonstrating that companies avoid reporting higher earnings so as not to catch the regulator's attention and ensure positive results in the future.

REINS (control) - percentage of insurance premiums issued by insurer $\mathrm{i}$ in calendar year $\mathrm{t}$ ceded in reinsurance (reinsurance premium ceded).

This variable was included in the model, since studies by Harrington and Danzon (1994), followed by studies by Grace and Leverty (2012) and Sun et al. (2012), found evidence that insurers concealed undervaluation through reinsurance. According to the findings of these 
works, reinsurance operations seem to generate a tendency for under-provision, that is, once the insurer knows that it will be reimbursed, it reduces the conservatism in its measurement of claims. Therefore, it is expected that the REINS variable will be negatively and significantly related to the estimation error.

LNAT (control) - is the value of the natural logarithm of the total assets recorded by insurer $\mathrm{i}$ in year $\mathrm{t}$.

This control was included in the model because there are contradictions in the literature about the existence or not of the relation between the size of the insurer and the precision of the claims provisions. Aiuppa and Trieschmann (1987) found evidence that the largest insurers show more accuracy in the estimation process than smaller ones, due to better actuarial support and greater experience in this process. Rodrigues (2008) and Sun et al. (2012) found a significant negative relationship between the size of the insurer and the amount of the claims liability. In addition, Weiss (1985) and Petroni (1992), Eckles and Halek (2010), and Eckles et al. (2011) did not find any effect of the size of the company on the estimation error. For all this, the expected coefficient for LNAT is indeterminate, being positive or negative.

Table 4 contains the set of variables used in this study and their algebraic formulations, relating them to the stated hypotheses.

Table 4

Panel of variables used in the regression model

\begin{tabular}{|c|c|c|c|}
\hline $\begin{array}{l}\text { Associated } \\
\text { Hypothesis }\end{array}$ & Variable & Formula & Expected Sign \\
\hline \multirow{2}{*}{---} & \multirow{2}{*}{$\underset{\text { it }}{\text { ERROR }_{2}}$} & $\underset{\text { it }}{\text { Incurred Claims - Incurred Claims }} \underset{\mathrm{it}+\mathrm{j}}{ }$ & \multirow{2}{*}{--- } \\
\hline & & Earned premiums & \\
\hline \multirow[b]{2}{*}{$\mathrm{H}_{1}$} & \multirow[b]{2}{*}{ IRCS $_{\text {it }}$} & Adjusted IRPJ + Adjusted CSLL & \multirow[b]{2}{*}{$(+)$ and sig. } \\
\hline & & Total Assets & \\
\hline \multirow{3}{*}{$\mathrm{H}_{2}$} & \multirow{3}{*}{$\mathrm{SUFCAP \%}_{\text {it }}$} & Adjusted CRA - MCR & \multirow{3}{*}{$(+)$ and sig. } \\
\hline & & it it & \\
\hline & & MCR & \\
\hline \multirow{3}{*}{$\mathrm{H}_{3}$} & \multirow{3}{*}{ NETMAR $_{\text {it }}$} & Adjusted Net Income & \multirow{3}{*}{$(+)$ and sig. } \\
\hline & & & \\
\hline & & Earned Premiums & \\
\hline \multirow{2}{*}{ Control } & \multirow{2}{*}{ REINS $_{\text {it }}$} & 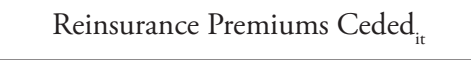 & \multirow{2}{*}{$(-)$ and sig. } \\
\hline & & Written Premiums & \\
\hline Control & LNAT & Natural Logarithm of Total Assets & undetermined \\
\hline
\end{tabular}

The accounting and financial data (total assets, technical provisions by branch, written premiums, earned premiums, reinsurance premiums ceded, IRPJ and CSLL expenses, and net income) of the sample insurers were taken from the financial statements generated in SUSEP's Statistics System (SES), available on the local authority's website (Superintendência de Seguros Privados, 2014). Those related to solvency were consulted in the internal database of Susep. In addition, estimation errors were extracted from the claims development tables 
disclosed in the notes to the annual individual financial statements of 2013, published by the sample companies in the official gazette and in a large circulation newspaper, and also available on the Susep website (Superintendência de Seguros Privados, 2015).
The empirical evidence was tested in the following pooled multiple linear regression model with specific accruals and ordinary least squares (OLS) estimation:

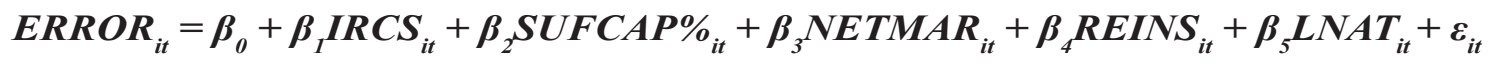

This model was based on those developed by Rodrigues (2008), but adapted to the solvency parameter in force in the years analyzed (inclusion of the minimum capital requirement) and, mainly, improved using the estimation error as a dependent variable, as in the international studies by Kazenski, Feldhaus, and Schneider (1992), Petroni (1992), Gaver and Paterson (1999),
Beaver et al. (2003), Gaver and Paterson (2004), Eckles and Halek (2010), Eckles et al. (2011), Grace and Leverty (2012), and Sun, Wei, and $\mathrm{Xu}(2012)$.

\section{Analysis of Results}

Table 5 presents descriptive statistics in order to analyze the sample data.

Table 5

Descriptive statistics of the variables for the sample of 133 observations in the years 2008-2010

\begin{tabular}{lcccccccc}
\hline Variables & $\boldsymbol{N}$ & Mean & $\begin{array}{c}\text { Standard } \\
\text { deviation }\end{array}$ & Minimum & 1st quartile & Median & 3rd quartile & Maximum \\
\hline ERROR & 133 & 3.4818 & 14.0754 & -1.0945 & -0.0578 & 0.0155 & 0.8713 & 142.8053 \\
IRCS & 133 & 0.0531 & 0.2051 & -0.3341 & 0.0001 & 0.0163 & 0.0553 & 1.4016 \\
SUFCAP\% & 133 & 1.1291 & 2.4778 & -0.8188 & 0.1426 & 0.3846 & 1.1649 & 19.6939 \\
NETMAR & 133 & 2.4183 & 9.6534 & -0.9136 & 0.0124 & 0.1189 & 0.9186 & 101.6390 \\
REINS & 133 & -0.1777 & 0.2835 & -0.9613 & -0.1739 & -0.0427 & -0.0055 & 0.0031 \\
LNAT & 133 & 13.1524 & 1.9838 & 9.7996 & 11.7789 & 13.0722 & 14.5036 & 18.2160 \\
\hline
\end{tabular}

Note. ERROR = difference between the initial estimate of claims occurring in a given year $\mathrm{t}$ and the amount re-estimated for the same set of incurred claims after three years, scaled by the total earned premiums; IRCS = sum of the adjusted balances of the corporate income tax and social contribution on net profit expense accounts, scaled by the total recognized assets; SUFCAP\% = percentage of sufficiency of capital resources available, adjusted by the estimation error (net of taxation), in relation to the minimum capital requirement; NETMAR = net margin calculated from the net income adjusted by the estimation error (net of taxation); REINS = percentage of issued insurance premiums ceded in reinsurance; and LNAT = natural logarithm of total assets recorded.

The mean (median) of the dependent variable is positive and represents about 3.48 (0.01) times the earned premiums obtained by the companies in the sample. For every $\mathrm{R} \$ 1.00$ of earned premiums, $\mathrm{R} \$ 3.48(\mathrm{R} \$ 0.02)$ of loss provisions are over-provisioned. Thus, the average of the sample behavior may be an indication of the use of the estimation of loss provisions for the purpose of reducing taxes, since positive errors represent overprovisioning and a consequent reduction of the accounting and taxable income for the period.

Regarding the variables of interest, the taxes on profit adjusted by the estimation errors, that is, before the discretionary exercise, had a mean (median) of $5.31 \%(1.63 \%)$ of total assets, that is, for every $\mathrm{R} \$ 1.00$ of recorded assets, approximately $\mathrm{R} \$ 0.05(\mathrm{R} \$ 0.02)$ was 
incurred in expenses related to corporate income tax and social contribution on net profits. The sufficiency of adjusted shareholders' equity before the discretionary exercise against the minimum capital requirement of the sample companies had a mean (median) of $112.91 \%$ (38.46\%) in the period. The average net margin adjusted for the loss provision error was $241.83 \%$ (11.89\%), meaning that, on average, for every $\mathrm{R} \$ 1.00$ of earned premium, $\mathrm{R} \$ 2.42$ ( $\mathrm{R} \$ 0.11$ ) become company profit.

Compared to the international studies (for example, Grace, 1990; Petroni, 1992; Beaver et al., 2003; Sun, Wei, \& Xu, 2012), the Brazilian data for ERROR, SUFCAP\%, and NETMAR was naturally more dispersed. However, the differential of this research in terms of variables and analyzed market does not exist in national studies, which would allow a more rigorous comparison of the statistics mentioned.

Finally, a mean (median) of approximately $17.77 \%(4.27 \%)$ of the premiums issued by the sample companies were ceded in reinsurance and the logarithm of the average total assets recognized was equal to 13.1524 (13.0722). The average firm has $\mathrm{R} \$ 4,023$ million (475,519 thousand) in registered assets.

Regarding the managers' incentives to undervalue or overvalue their claims provisions, Table 6 summarizes the results of the pooled OLS multiple linear regression analysis obtained with the Gretl software.

Table 6

Regression results with robust standard error correction for the sample of 133 observations in the years 2008-2010

\begin{tabular}{|c|c|c|c|c|c|}
\hline Variable & Expected Sign & Coefficient & Standard error & $\mathbf{t}$ & p-value \\
\hline Constant & $+/-$ & 1.0572 & 0.7270 & 1.454 & 0.1483 \\
\hline IRCS & + & $1.1076^{* * *}$ & 0.2733 & 4.052 & 0.0000 \\
\hline SUFCAP\% & + & $0.1296^{* * *}$ & 0.0333 & 3.890 & 0.0002 \\
\hline NETMAR & + & $1.4248^{* * *}$ & 0.0325 & 43.84 & 0.0000 \\
\hline REINS & - & -0.2471 & 1.5394 & -0.1605 & 0.8727 \\
\hline LNAT & $+/-$ & -0.0966 & 0.0596 & -1.621 & 0.1075 \\
\hline Other information & & & Other information & \multicolumn{2}{|c|}{ Value } \\
\hline $\mathrm{R}^{2}$ & & & F (stat.) & \multicolumn{2}{|c|}{739.7703} \\
\hline $\mathrm{R}^{2}$ Adjusted & & & $\mathrm{F}$ (p-value) & \multicolumn{2}{|c|}{0.0000} \\
\hline Chi-squared (p-value) & & & Breusch-Pagan (p-value) & \multicolumn{2}{|c|}{0.0000} \\
\hline Durbin-Watson (stat.) & & & Durbin-Watson (p-value) & \multicolumn{2}{|c|}{0.8655} \\
\hline
\end{tabular}

Note. IRCS = sum of the adjusted balances of the corporate income tax and social contribution on net profit expense accounts , scaled by total recognized assets; SUFCAP\% = percentage of sufficiency of capital resources available, adjusted by the estimation error (net of taxation), in relation to the minimum capital requirement; NETMAR = net margin calculated with net income adjusted by the estimation error (net of taxation); REINS = percentage of issued insurance premiums ceded in reinsurance; and LNAT = natural logarithm of total registered assets. ${ }^{*},{ }^{* *}$ and ${ }^{* * *}=$ level of statistical significance lower than $10 \%, 5 \%$, and $1 \%$, respectively.

As for the tests of the assumptions of the model, the findings did not have a normal distribution (Chi-squared p-value $<1 \%$ ). According to Brooks (2008), in the presence of a sample of reasonable size, we can use the Central
Limit Theorem (TLC) and consider that the statistical tests of the OLS estimation will follow the appropriate distributions asymptotically. Thus, considering that the sample has 133 observations, the premise was relaxed based on 
TLC. The Breusch-Pagan test revealed that the error terms are not homoskedastic (B-P p-value $<1 \%$ ). For this reason, we used White's robust standard error correction to treat the detected heteroskedasticity (Wooldridge, 2006).

Regarding the other assumptions, no multicollinearity was identified (VIF equal to 1.582 and correlation between the independent variables equal to 0.40$)$. In addition, the data are pooled, which makes the serial autocorrelation test unnecessary (Fávero, Belfiore, Silva, \& Chan, 2009). Nevertheless, the Durbin-Watson test did not signal a violation of this premise (D-W p-value $>1 \%$ ).

In addition, the model was adequate to explain the behavior of the errors of the claims provisions ( $\mathrm{F}$ p-value $<1 \%$ ), and the independent variables selected were able to explain $97.30 \%$ of the reported error variations.

According to the t test result, the parameter of the tax regulation variable has statistical significance at the $1 \%$ level of significance (p-value of IRCS $=0.0000$ ) and, therefore, the null hypothesis is rejected that it is equal to zero at this level. Regarding the objective of analyzing the tax incentive for earnings management through loss reserves, there is a positive relationship between IRCS and ERROR; that is, companies that would have higher tax on profit values if they recognized the correct value of such provisions tend to overestimate them in order to reduce profit and therefore the tax amounts due.

Thus, $\mathbf{H}_{\mathbf{1}}$ is confirmed in the sense that insurance companies use claims provisions related to property and casualty operations with a view to reducing taxes due. Therefore, tax regulation would be an incentive for earnings management through these provisions. This finding is in line with those of Rodrigues (2008) in the Brazilian market, and Grace (1990), Peñalva (1998), Gaver and Paterson (1999), Nelson (2000), Beaver et al. (2003), and Grace and Leverty (2012) in the North American market. However, Petroni (1992), Eckles and Halek (2010), and Eckles et al. (2011) did not find the relation cited.
Likewise, the angular coefficient of the performance variable used presented statistical significance at the $1 \%$ level (p-value of NETMAR $=0.0000)$, therefore being different from zero, besides being positively related to the estimation errors. In other words, on average, the better the performance of the sample insurers, disregarding the estimation error, the greater the values of their claims provision estimation errors, thus leaving $\mathbf{H}_{3}$ confirmed.

This means that the performance of these companies constitutes an incentive for an overvaluation in the initial measurement of loss provisions, biasing them (earnings management) and, with this, reducing profits and related taxes, besides drawing less regulator and shareholder attention to abnormal profits. It is important to note that this behavior is probably carried out in a way that does not make the solvency parameter negative, which could catch the attention of the regulator and generate costs of closer inspection. This result is in agreement with those of Weiss (1985), Grace (1990), Beaver et al. (2003), and Rodrigues (2008), and is in line with the findings of Grace and Leverty (2012).

With respect to the economic regulation variable, again there is statistical significance at the $1 \%$ level and a positive relation with the estimation errors of the loss provisions ( $\mathrm{p}$-value of SUFCAP\% $=0.0000$ ). Thus, $\mathbf{H}_{2}$ is confirmed in the sense that insurers that would have lower levels of the solvency parameter [(CRA - MCR) / $M C R]$, if there were no error in the measurement of the loss provisions, on average, undervalue their initial measurement of these provisions to increase the result by improving the solvency parameter; thereby avoiding or delaying the costs of more thorough actions by the insurance market regulator.

Thus, there is evidence of the use of managerial discretion in the measurement of claims provisions with the objective of improving the solvency parameter used by Susep to take regulatory actions. This evidence is in addition to the findings of Petroni (1992), Gaver and 
Paterson (1999), Gaver and Paterson (2004), and Grace and Leverty (2012) and extends those of Rodrigues (2008), since it uses the reported estimation error in the explanatory notes, a rare opportunity for direct detection of the discretion exercised by insurance managers over the claims provision as a specific accrual (Petroni, 1992).

Thus, the political costs hypothesis predicted by Watts and Zimmerman (1990) finds support in the evidence of this study for the Brazilian insurance market, since the companies in this market seem encouraged to avoid raising the tax rate and alerting the regulator to the need for greater regulatory capital requirements. In addition, it aligns with the research cited by Healy and Wahlen (1999) in that government regulation is confirmed as an incentive for the earnings management of insurers.

Finally, the parameters of the constant and the variables that sought to control the reinsurance operations (REINS) and size (LNAT) factors were not statistically significant. For size effect, these results are in agreement with studies by Weiss (1985) and Petroni (1992), Eckles and Halek (2010), and Eckles et al. (2011), and contrary to the findings of Aiuppa and Trieschmann (1987) and Gaver and Paterson (2004), in that no evidence was found that size influences the accuracy of the initial measurement of claims provisions. Regarding the volume of reinsurance, the results are consistent with those of Harrington and Danzon (1994), Grace and Leverty (2012), and Sun et al. 2012).

The comparison of the significance of the IRCS and economic parameters (SUFCAP\%) shows that the tax regulation incentive is more significant for managers than the economic regulation incentive. This may be a result of the high tax burden in the country, especially for the financial sector, which can reach nominal levels of $40 \%$. Thus, insurance managers seem to be more concerned with this aspect than with improving the solvency parameters in force in the years analyzed. Another possible justification for this behavior may be the partial adoption of Solvency
II in the three years of the study, in which only the underwriting risk already captured in part by the solvency margin (tested in this paper) was standardized, leaving the financial risks (market and credit) and the operational risks related to the internal operation of the company. The regulation of all risk capital will make the requirement more robust and certainly deserves attention in future studies on incentives for earnings management in this market.

\section{Conclusion}

This study sought to investigate whether insurance companies use the estimation errors of claims provisions (OCP and IBNR) related to property and casualty insurance to manage their accounting information in order to avoid more detailed regulatory actions by the State and to reduce the relative amounts due for taxation on profit.

After gathering the aforementioned errors and the other variables of the research, we made use of pooled OLS regression analysis with a specific model of accruals and the results showed that the managers of the insurers use their freedom of judgment in relation to claims provision errors to manage their accounting information with a view to reducing taxable profits and, consequently, paying less taxes, thus confirming $\mathbf{H}_{1}$. This evidence is supported by previous studies such as those of Grace (1990), Gaver and Paterson (1999), Rodrigues (2008), and Grace and Leverty (2012), and the evidence found in Healy and Wahlen (1999), which showed the government regulation of specific sectors as a motivator for earnings management.

In addition, as in Petroni (1992), Gaver and Paterson (1999), Gaver and Paterson (2004), Rodrigues (2008), and Grace and Leverty (2012), the findings of this study show the use of this discretion in order to improve solvency parameters and thus draw less attention from the market regulator. Thus, $\mathbf{H}_{2}$ is confirmed. It is argued that the relationship between the estimation errors (specific accrual used to measure 
accounting information bias) and the incentive of tax regulation was more significant than with the incentive of economic regulation. One possible explanation seems to be the combination of the increased tax rate exercised in the Brazilian insurance market with the beginning of the riskbased supervision adopted in the years analyzed. In the Brazilian insurance market, taxation on profits can reach the nominal rate of $40 \%$ on PBIT, due to the increased CSLL rate practiced on insurance companies. 2008, 2009, and 2010 were the first years in which Susep practiced riskbased supervision, and insurers were not required to take all the risk capital that would conceptually cause the insurers' capital requirement to rise because they considered other risks in addition to the underwriting risk. In other words, the level of eligible capital that the companies had in the years analyzed possibly exceeded that demanded, leading to managers prioritizing the reduction of tax payments in their decisions.

Finally, we confirmed $\mathbf{H}_{3}$, since the results indicate that the companies with better performance, disregarding the estimation error, tend on average to overestimate their claims provisions, thus reducing reported earnings to levels that do not catch the attention of the regulator and shareholders. These results are consistent with those found by Weiss (1985), Grace (1990), Beaver et al. (2003), and Rodrigues (2008), and contrary to those of Grace and Leverty (2012).

From the results of this research, it is possible to perceive that the behavior of the managers of property and casualty insurers may be associated with the costs and benefits of more optimistic disclosure than the actual economic and financial situation of the company, which contributes to greater informational asymmetry in the market.

As a result, regulators can improve standards to reduce managerial discretion, for example by increasing the requirement for an appropriate corporate governance structure or more effective audit committee, or by encouraging actuarial and accounting audits. In addition, this research enables the insurance market and its agents, including the regulator, to evaluate companies more comprehensively. The accounting and financial disclosures of insurers should be used with caution for the purposes of liquidity and solvency analysis, as they may not reflect the economic and financial situation of the companies due to deviations in the measurement of insurance liabilities, and it is prudent to observe in the development table the magnitude and direction of the errors of loss provisions to judge the accuracy of these liabilities and evaluate the risks and returns when making decisions regarding the allocation of resources or regulatory action.

Among the limitations of this research, we can mention: (i) the subjectivity present in the analysis of explanatory notes, which involves personal interpretations and decoding by the researcher; (ii) the exclusive use of explanatory notes for the collection of estimation errors, which prevents the triangulation of data, leaving open the possibility of errors in the disclosed data; (iii) the estimation errors found in this study may have been mitigated by the introduction of the liability adequacy test in the Brazilian insurance market; and (iv) limiting the study period to 2008, 2009, and 2010, the first years of the adoption of risk-based supervision, due to the need to allow sufficient time to develop insurance claims.

\section{References}

Aiuppa, T. A., \& Trieschmann, J. S. (1987). An empirical analysis of the magnitude and accuracy of incurred-but-not-reported reserves. Journal of Risk and Insurance, 54(1), 100-118.

Bagnati V. H. C. (2012). Analysis and challenges of IFRS 4 (fase II) - Insurance Contracts (Master's dissertation). Pontifical Catholic University of São Paulo, SP, Brazil.

Beaver, W. H., McNichols, M. F., \& Nelson, K. K. (2003). Management of the loss reserve accrual and the distribution of earnings in the property- 
casualty insurance industry. Journal of Accounting and Economics, 35(3), 347-376.

Brooks, C. (2008). Introductory econometrics for finance (2nd ed.). Cambridge: Cambridge University Press.

Cardoso, R. L. (2005). Economic regulation and accounting choice: Evidences from Brazilian health maintenance organizations (Doctoral thesis). Faculty of Economics, Business, and Accounting, São Paulo University, São Paulo, SP, Brazil.

CNSP Resolution No. 178, of December 17, 2007. (2007). Provides for a minimum capital requirement for the authorization and operation of insurance companies and provides other measures. Retrieved on December 03, 2014, from http://www2.susep.gov.br/bibliotecaweb/ biblioteca.aspx

CNSP Resolution No. 222, of December 6, 2010. (2010). Establishes rules and procedures for calculating the adjusted shareholders' equity (minimum capital requirement) of insurance companies, local reinsurance companies, rafflelinked savings companies, and publicly-held private pension entities. Retrieved on December 06, 2014, from http://www2.susep.gov.br/ bibliotecaweb/biblioteca.aspx

CNSP Resolution No. 282, of January 30, 2013. (2013). Provides for minimum capital requirement for both the authorization and operation, and solvency plans, of insurance companies, publiclyheld private pension entities, raffle-linked savings companies, and local reinsurance companies. Retrieved on December 05, 2014, from http:// www2.susep.gov.br/bibliotecaweb/biblioteca.aspx

Comitê de Pronunciamentos Contábeis. (2011). Conceptual Framework (R1): Conceptual Framework for Financial Reporting. Retrieved on 03 December, 2013, de http://www.cpc.org.br/ pdf/CPC00_R1.pdf

Costa, J. A. (2005). Insurance accounting: The experiences in Brazil and in Mercosul compared to the IASB's standards. Rio de Janeiro: Funenseg, Série Cadernos de Seguros: Thesis.

Decree No. 3000, of March 26, 1999. (1999). Regulates the taxation, inspection, collection, and administration of Corporate Income Tax and any kind of income. Retrieved on December 06, 2014 , from de https://www.planalto.gov.br/ccivil_03/ decreto/D3000.htm

Decree-Law No. 73, of November 21, 1966. (1966). Provides for the National Private Insurance System, regulates insurance and reinsurance operations, and provides other measures. Retrieved on December 06, 2014, from http://www.planalto.gov.br/ccivil_03/DecretoLei/del0073compilado.htm

Eckles, D. L., \& Halek, M. (2010). Insurer reserve error and executive compensation. The Journal of Risk and Insurance, 77(2), 329-346.

Eckles, D. L., Halek, M., He, E., Sommer, D. W., \& Zhang, R. (2011). Earnings smoothing, executive compensation, and corporate governance: Evidence from the property-liability insurance industry. The Journal of Risk and Insurance, 78(3), 761-790.

European Insurance and Occupational Pensions Authority. (2013). Solvency II. Retrieved on November 05, 2013, from https://eiopa.europa. eu/en/activities/insurance/solvency-ii/index.html

Fávero, L. P., Belfiore, P., Silva, F. L., \& Chan, B. L. (2009). Data analysis: Multivariate modeling for decision making. Rio de Janeiro: Elsevier.

Gaver, J. J., \& Paterson, J. S. (1999). Managing insurance company financial statements to meet regulatory and tax reporting goals. Contemporary Accounting Research, 16(2), 1-40, 1999.

Gaver, J. J., \& Paterson, J. S. (2004). Do insurers manipulate loss reserves to mask solvency problems? Journal of Accounting and Economics, 37(3), 393-416. 
Gonçalves, R. S. (2015). Accounting analysis of the liability adequacy test performed by companies regulated by Susep in the period from 2011 to 2014 (Master's dissertation). Federal University of Rio de Janeiro, RJ, Brazil.

Grace, E. V. (1990). Property-liability insurer reserve errors: A theorical and empirical analysis. The Journal of Risk and Insurance, 57(1), 28-46.

Grace, M. F., \& Leverty, J. T. (2012). Property-liability insurer reserve error: Motive, manipulation, or mistake. The Journal of Risk and Insurance, 79(2), 351-380.

Harrington, S. E., \& Danzon, P. M. (1994). Price cutting in liability insurance markets. Journal of Business, 67(4), 511-538.

Healy, P. M., \& Wahlen, J. M. (1999). Review of the earnings management literature and its implications for standard setting. Accounting Horizons, 13(4), 365-384.

Houlthausen, R. W., \& Leftwich, R. W. (1983). The economic consequences of accounting choice implications of costly contracting and monitoring. Journal of Accounting and Economics, 5(1), 77-117.

Kazenski, P. M., Feldhaus, W. R., \& Schneider, H. C. (1992). Empirical evidence for alternative loss development horizons and the measurement of reserve error. Journal of Risk and Insurance, 59(4), 668-681.

Law No. 7.689, of December 15, 1988. (1988). Provides for the social contribution on net income (CSLL) and makes other provisions. Retrieved on December 03, 2014, from http://www.planalto. gov.br/ccivil_03/_ato2007-2010/2008/lei/ 111727.htm

Lopes, A. B., \& Martins, E. (2005). Accounting theory: A new approach. São Paulo: Atlas.

Martire, A. L. (2012). Embedded surrender option pricing for equity-linked policies: Comparisons and solutions for bivariate models (Doctoral thesis). Economics Postgraduate School of Rome University, Rome, Italy.

Melo, E. E., \& Neves, C. R. (2012). Valuation of assets and obligations of insurers for solvency purposes. In E. E. Melo, \& C. R. Neves (Coord.), Solvency in insurance and private pension market: collection of studies (pp. 5-22). Rio de Janeiro: Escola Nacional de Seguros - Funenseg.

Nelson, K. K. (2000). Rate regulation, competition, and loss reserve discounting by property-casualty insurers. The Accounting Review, 75(1), 115-138.

Paulo, E. (2007). Manipulation of accounting information: A theoretical and empirical analysis on the operational models of earnings management detection (Doctoral thesis). Faculty of Economics, Business and Accounting, São Paulo University, São Paulo, SP, Brazil. v. 1.

Peñalva, A. F. (1998). Loss reserves and accounting discretion in the property-casualty insurance industry (Ph.D. Dissertation). University of California, Berkeley.

Petroni, K. (1992). Optimistic reporting in the property-casualty insurance industry. Journal of Accounting and Economics, 15(4), 485-508.

Posner, R. A. (1974). Theories of economic regulation. The Bell Journal of Economics and Management Science, 5(2), 335-358.

Rodrigues, A. (2008). Accounting information management and regulation: Evidences in the Brazilian insurance market (Doctoral thesis). Faculty of Economics, Business and Accounting, São Paulo University, São Paulo, SP, Brazil.

Stigler, G. J. (1971). The theory of economic regulation. The Bell Journal of Economics and Management Science, 2(1), 3-21.

Sun, F., Wei, X., \& Xu, Y. (2012). Audit committee characteristics and loss reserve error. Managerial Auditing Journal, 27(4), 355-377. 
Superintendência de Seguros Privados (2014). Sistema de Estatísticas da Susep (SES). Retrieved on December 06, 2014, from http://www2.susep. gov.br/menuestatistica/SES/principal.aspx

Superintendência de Seguros Privados (2015). Interim and Annual Financial Reporting. Retrieved on February 11, 2015, from http://www.susep. gov.br/setores-susep/cgsoa/coaso/demonstracoesfinanceiras-intermediarias-e-anuais

Susep Circular No. 355, of December 14, 2007. Provides for the underwriting risk of insurance companies by amending the annexes to CNSP Resolution No. 158/2006 and makes other provisions. Retrieved on December 03, 2014, de http://www2.susep.gov.br/bibliotecaweb/ biblioteca.aspx

Susep Circular No. 356, of December 20, 2007. Provides for changes in Brazilian insurance accounting standards to be observed by insurance companies, local reinsurance companies, rafflelinked savings companies, and publicly-held private pension entities established by CNSP Resolution No. 86 of August 19, 2002. Retrieved on February 11, 2015, from http://www2.susep. gov.br/bibliotecaweb/biblioteca.aspx

Susep Circular No. 408, of August 23, 2010. Provides for the accounting standards related to the fiscal year of 2010 and the presentation of the Periodic Information Forms, amends SUSEP Circular No. 379 of December 19, 2008, and makes other provisions. Retrieved on February 11, 2015, from http://www2.susep.gov.br/ bibliotecaweb/biblioteca.aspx

Susep Circular No. 410, of December 22, 2010. Establishes the liability adequacy test for the preparation of the financial statements and sets out rules and procedures for its realization, to be observed by insurance companies, publicly-held private pension entities, and local reinsurers. Retrieved on October 21, 2016, from http:// www2.susep.gov.br/bibliotecaweb/biblioteca.aspx

Susep Circular No. 446, of July 4, 2012. Provides for the suspension of the effects of Susep Circular
No. 410 of December 22, 2010. Retrieved on October 21, 2016, from http://www2.susep.gov. $\mathrm{br} /$ bibliotecaweb/biblioteca.aspx

Susep Circular No. 457, of December 14, 2012. Establishes the Liability Adequacy Test for the purpose of preparing financial statements and sets out rules and procedures for its realization, to be observed by insurance companies, publiclyheld private pension entities, and local reinsurers. Retrieved on October 21, 2016, from http:// www2.susep.gov.br/bibliotecaweb/biblioteca.aspx

Susep Circular No. 517, of July 30, 2015. Provides for technical provisions; the liability adequacy test; reducing assets; underwriting, credit, operating, and market risk capital; the creation of a database of operational losses; solvency plans; recording, custody, and movement of assets and securities that cover technical provisions; the Periodic Information Form - FIP / SUSEP; accounting standards and independent accounting audits of insurers, publicly-held private pension entities, raffle-linked savings companies, and reinsurers; application test, certification test, and continuing professional education of the independent accounting auditor; and the technical pronouncements prepared by the Brazilian Actuarial Institute - IBA. Retrieved on October, 21, 2016, from http://www2.susep.gov. br/bibliotecaweb/bi blioteca.aspx

Watts, R. L., \& Zimmerman, J. L. (1990). Positive accounting theory: A ten year perspective. The Accounting Review, 65(1), 131-156.

Weiss, M. A. (1985). A multivariate analysis of loss reserving estimates in property-liability insurers. Journal of Risk and Insurance, 52(2), 199-221.

Wooldridge, J. M. (2006). Introductory econometrics: A modern approach. Boston: Cengage Learning.

Zsoldos, P. (2014). How to measure adequacy of technical provisions in general insurance practical perspective. European Scientific Journal, special (special), 325-332. 


\section{Appendix A}

In order to clarify the collected data, Table 7 presents the hypothetical development of the claims of an insurer in the period from 2008 to 2013. We calculated the example estimation errors three years after the initial constitution, according to the methodology adopted in this research.

Table 7

\section{Example of a claims development table for the period 2008-2013}

\begin{tabular}{|c|c|c|c|c|c|c|}
\hline \multirow{2}{*}{$\begin{array}{l}\text { Incurred claims and expenses } \\
\text { reported... }\end{array}$} & \multicolumn{6}{|c|}{ Incurred claims and accrued expenses reported at the end of the year } \\
\hline & $\begin{array}{l}\text { Up until } \\
2008\end{array}$ & 2009 & 2010 & 2011 & 2012 & 2013 \\
\hline At the end of the year $(t)$ & 3,000 & 500 & 800 & 900 & 500 & 750 \\
\hline 1 year later $(t+1)$ & 3,500 & 450 & 600 & 1,000 & 450 & \\
\hline 2 years later $(t+2)$ & 3,250 & 600 & 750 & 1,100 & & \\
\hline 3 years later $(t+3)$ & 3,300 & 700 & 650 & & & \\
\hline 4 years later $(t+4)$ & 3,450 & 650 & & & & \\
\hline 5 years later $(t+5)$ & 3,500 & & & & & \\
\hline Current estimate & 3,500 & 650 & 650 & 1,100 & 450 & 750 \\
\hline \multicolumn{7}{|l|}{ Error Calculation: } \\
\hline Initial estimate $(\mathrm{t})$ & 3,000 & 500 & 800 & 900 & 500 & 750 \\
\hline Revised estimate $(t+3)$ & 3,300 & 700 & 650 & - & - & - \\
\hline Estimation error & $(300)$ & $(200)$ & 150 & - & - & - \\
\hline Situation & $\begin{array}{l}\text { undervalued } \\
\text { provision in } \mathrm{t}\end{array}$ & $\begin{array}{l}\text { undervalued } \\
\text { provision in } t\end{array}$ & $\begin{array}{l}\text { undervalued } \\
\text { provision in } \mathrm{t}\end{array}$ & $\begin{array}{c}\text { incomplete } \\
\text { development }\end{array}$ & $\begin{array}{l}\text { incomplete } \\
\text { development }\end{array}$ & $\begin{array}{l}\text { incomplete } \\
\text { development }\end{array}$ \\
\hline
\end{tabular}

The first column (up to 2008) shows the initial estimate $(\$ 3,000)$ for the series of incurred claims until the end of 2008 (first line, t) and successive restatements up to the end of 2013 (\$3,500): \$3,250, $\$ 3,300, \$ 3,450$, and $\$ 3,500$, respectively, from $t+1$ to $t+5$. At the end of fiscal year $2011(t+3)$, the reestimate was $\$ 3,300$ and the estimation error, therefore, was $\$ 300$ negative, indicating an understatement in the initial recognition of the set of claims represented in the respective column. The third column (2010) presents the initial estimate ( $\$ 800)$ for all claims occurring only during 2010 (first line, $t$ ) and successive reestimates during the following years up to 2013 ( $\$ 600$ at $t+1, \$ 750$ at $t+2, \$ 650$ at $t+3$ ). Thus, the estimation error of the provisions for claims for 2010 was $\$ 150$ positive, that is, observed three years later, the provisions for claims regarding the occurrences of 2010 were overvalued. It should be noted that the exact amount of the estimation error of a given year will be known only after payment of all incurred claims over that same period. However, the insurer is expected to revise the estimates gradually over the years by making them increasingly close to the settlement value of the claims set. 


\section{Appendix B}

Table 8

\section{Companies included in the sample in each of the years analyzed}

\begin{tabular}{|c|c|c|c|c|}
\hline N. & Sample companies & 2008 & 2009 & 2010 \\
\hline 1 & Ace Seguradora S.A. & $\mathrm{X}$ & $\mathrm{X}$ & $\mathrm{X}$ \\
\hline 2 & Alfa Previdência e Vida S.A. & $\mathrm{X}$ & $\mathrm{X}$ & \\
\hline 3 & Alfa Seguradora S.A. & $\mathrm{X}$ & $\mathrm{X}$ & $\mathrm{X}$ \\
\hline 4 & Aliança do Brasil Seguros S.A. & $\mathrm{X}$ & $\mathrm{X}$ & $\mathrm{X}$ \\
\hline 5 & Allianz Seguros S.A. & $\mathrm{X}$ & $\mathrm{X}$ & $\mathrm{X}$ \\
\hline 6 & American Life Companhia de Seguros & $\mathrm{X}$ & & \\
\hline 7 & Assurant Seguradora S.A. & $\mathrm{X}$ & $\mathrm{X}$ & $\mathrm{X}$ \\
\hline 8 & Banestes Seguros S.A. & $\mathrm{X}$ & $\mathrm{X}$ & $\mathrm{X}$ \\
\hline 9 & Berkley International do Brasil Seguros S.A. & $\mathrm{X}$ & $\mathrm{X}$ & $\mathrm{X}$ \\
\hline 10 & Bradesco Auto/Re Companhia de Seguros & $\mathrm{X}$ & $\mathrm{X}$ & $\mathrm{x}$ \\
\hline 11 & Bradesco Vida e Previdência S.A. & $\mathrm{X}$ & $\mathrm{X}$ & $\mathrm{X}$ \\
\hline 12 & Brasilveículos Companhia de Seguros & $\mathrm{X}$ & $\mathrm{X}$ & $\mathrm{X}$ \\
\hline 13 & Cardif do Brasil Seguros e Garantias S.A. & $\mathrm{X}$ & $\mathrm{X}$ & $\mathrm{x}$ \\
\hline 14 & Chubb do Brasil Companhia de Seguros & $\mathrm{X}$ & $\mathrm{X}$ & $\mathrm{X}$ \\
\hline 15 & Coface do Brasil Seguros de Crédito S.A. & $\mathrm{X}$ & $\mathrm{X}$ & $\mathrm{X}$ \\
\hline 16 & Companhia de Seguros Aliança do Brasil & $\mathrm{X}$ & $\mathrm{X}$ & $\mathrm{X}$ \\
\hline 17 & Crédito y Caución Seguradora de Crédito à Exportação S.A. & $\mathrm{X}$ & $\mathrm{x}$ & $\mathrm{X}$ \\
\hline 18 & Crédito y Caución Seguradora de Crédito e Garantias S.A. & $\mathrm{X}$ & $\mathrm{X}$ & $\mathrm{X}$ \\
\hline 19 & Euler Hermes Seguros de Crédito à Exportação S.A. & $\mathrm{X}$ & $\mathrm{X}$ & $\mathrm{X}$ \\
\hline 20 & Euler Hermes Seguros de Crédito S.A. & $\mathrm{X}$ & $\mathrm{x}$ & $\mathrm{X}$ \\
\hline 21 & HDI Seguros S.A. & $\mathrm{X}$ & $\mathrm{X}$ & $\mathrm{X}$ \\
\hline 22 & HSBC Seguros (Brasil) S.A. & $\mathrm{X}$ & $\mathrm{X}$ & $\mathrm{X}$ \\
\hline 23 & HSBC Vida e Previdência (Brasil) S.A. & $\mathrm{X}$ & $\mathrm{X}$ & $\mathrm{X}$ \\
\hline 24 & Icatu Seguros S.A. & & & $\mathrm{X}$ \\
\hline 25 & Indiana Seguros S.A. & $\mathrm{X}$ & $\mathrm{X}$ & $\mathrm{X}$ \\
\hline 26 & Investprev Seguradora S.A. & & $\mathrm{X}$ & $\mathrm{X}$ \\
\hline 27 & Investprev Seguros e Previdência S.A. & & $\mathrm{X}$ & $\mathrm{X}$ \\
\hline 28 & Itaú Seguros S.A. & & $\mathrm{X}$ & $\mathrm{X}$ \\
\hline 29 & Itaú Vida e Previdência S.A. & & $\mathrm{X}$ & $\mathrm{X}$ \\
\hline 30 & Liberty Seguros S.A. & $\mathrm{X}$ & $\mathrm{X}$ & $\mathrm{X}$ \\
\hline 31 & Luizaseg Seguros S.A. & $\mathrm{X}$ & $\mathrm{X}$ & $\mathrm{X}$ \\
\hline 32 & Mapfre Affinity Seguradora S.A. & $\mathrm{X}$ & $\mathrm{X}$ & $\mathrm{X}$ \\
\hline 33 & Mapfre Seguradora de Crédito à Exportação S.A. & $\mathrm{X}$ & & \\
\hline 34 & Mapfre Seguros Gerais S.A. & $\mathrm{X}$ & $\mathrm{X}$ & $\mathrm{X}$ \\
\hline 35 & Marítima Seguros S.A. & $\mathrm{X}$ & $\mathrm{X}$ & $\mathrm{X}$ \\
\hline 36 & Mitsui Sumitomo Seguros S.A. & & $\mathrm{X}$ & $\mathrm{X}$ \\
\hline 37 & Mongeral Aegon Seguros e Previdência S. A. & $\mathrm{X}$ & $\mathrm{X}$ & $\mathrm{X}$ \\
\hline 38 & Pan Seguros S.A. & $\mathrm{X}$ & $\mathrm{X}$ & $\mathrm{X}$ \\
\hline 39 & QBE Brasil Seguros S.A. & $\mathrm{X}$ & $\mathrm{X}$ & $\mathrm{X}$ \\
\hline 40 & Seguradora Brasileira de Crédito à Exportação S.A. & $\mathrm{X}$ & $\mathrm{X}$ & $\mathrm{X}$ \\
\hline
\end{tabular}




\begin{tabular}{|c|c|c|c|c|}
\hline N. & Sample companies & 2008 & 2009 & 2010 \\
\hline 41 & Sul América Companhia Nacional de Seguros & $\mathrm{X}$ & $\mathrm{X}$ & $\mathrm{X}$ \\
\hline 42 & Sul América Seguros de Pessoas e Previdência S.A. & $\mathrm{X}$ & $\mathrm{X}$ & $\mathrm{X}$ \\
\hline 43 & Unimed Seguradora S.A. & $\mathrm{X}$ & $\mathrm{X}$ & $\mathrm{X}$ \\
\hline 44 & Usebens Seguros S.A. & & $\mathrm{X}$ & $\mathrm{X}$ \\
\hline 45 & Vida Seguradora S.A. & $\mathrm{X}$ & & \\
\hline 46 & Virginia Surety Companhia de Seguros do Brasil & & $\mathrm{X}$ & $\mathrm{X}$ \\
\hline 47 & Yasuda Seguros S.A. & $\mathrm{X}$ & $\mathrm{X}$ & $\mathrm{X}$ \\
\hline 48 & Zurich Minas Brasil Seguros S.A. & $\mathrm{X}$ & $\mathrm{X}$ & \\
\hline 49 & Zurich Santander Brasil Seguros e Previdência S.A. & $\mathrm{X}$ & $\mathrm{X}$ & $\mathrm{X}$ \\
\hline 50 & Zurich Santander Brasil Seguros S.A. & $\mathrm{X}$ & $\mathrm{X}$ & $\mathrm{X}$ \\
\hline
\end{tabular}

\section{Notes:}

1 A preliminary version of the article "Claim Loss Reserve Error of Brazilian Insurance Companies: empirical evidence of the response to economic and tax regulations" was presented at the USP International Conference in Accounting, from $29^{\text {th }}$ to $31^{\text {th }}$ of July, 2015, in São Paulo.

\section{About the Authors:}

1. Rodrigo da Silva Santos Curvello, M.Sc. in Accounting, Federal University of Rio de Janeiro, Rio de Janeiro, Brazil. E-mail: prof.rodrigocurvello@gmail.com

\section{ORCID}

(iD) 0000-0001-5351-9269

2. Adriano Rodrigues, Post Doctorate in Financial Accounting, Suffolk University, Boston, United States of America. E-mail: adriano@facc.ufrj.br.

ORCID

(iD) 0000-0002-0099-0505

3. Marcelo Alvaro da Silva Macedo, Post Doctorate in Organizational Performance, University of São Paulo, São Paulo, Brazil. E-mail: malvaro@facc.ufrj.br.

ORCID

(iD) 0000-0003-2071-8661

\section{Contribution of each author}

\begin{tabular}{|c|c|c|c|}
\hline Contribution & $\begin{array}{l}\text { Rodrigo da Silva } \\
\text { Santos Curvello }\end{array}$ & $\begin{array}{c}\text { Adriano } \\
\text { Rodrigues }\end{array}$ & $\begin{array}{l}\text { Marcelo Alvaro da } \\
\text { Silva Macedo }\end{array}$ \\
\hline 1. Definition of research problem & $\sqrt{ }$ & $\sqrt{ }$ & \\
\hline $\begin{array}{l}\text { 2. Development of hypotheses or research questions (empirical } \\
\text { studies) }\end{array}$ & $\sqrt{ }$ & $\sqrt{ }$ & $\sqrt{ }$ \\
\hline 3. Development of theoretical propositions (theoretical work) & - & - & - \\
\hline 4. Theoretical foundation/Literature review & $\sqrt{ }$ & $\sqrt{ }$ & $\sqrt{ }$ \\
\hline 5. Definition of methodological procedures & $\sqrt{ }$ & $\sqrt{ }$ & $\sqrt{ }$ \\
\hline 6. Data collection & $\sqrt{ }$ & & \\
\hline 7. Statistical analysis & $\sqrt{ }$ & & $\sqrt{ }$ \\
\hline 8. Analysis and interpretation of data & $\sqrt{ }$ & $\sqrt{ }$ & $\sqrt{ }$ \\
\hline 9. Critical revision of the manuscript & $\sqrt{ }$ & $\sqrt{ }$ & $\sqrt{ }$ \\
\hline 10. Manuscript writing & $\sqrt{ }$ & & $\sqrt{ }$ \\
\hline
\end{tabular}

